\title{
Myostatin mRNA expression and its association with body weight and carcass traits in Yunnan Wuding chicken
}

\author{
L.X. Liu ${ }^{1,3 *}$, T.F. Dou ${ }^{1 *}$, Q.H. Li ${ }^{1}$, H. Rong ${ }^{1}$, H.Q. Tong ${ }^{1}$, Z.Q. Xu ${ }^{2}$, \\ Y. Huang ${ }^{1}$, D.H. Gu ${ }^{2}$, X.B. Chen ${ }^{1}$, C.R. Ge ${ }^{1}$ and J.J. Jia ${ }^{1}$ \\ ${ }^{1}$ Yunnan Provincial Key Laboratory of Animal Nutrition and Feed, \\ Yunnan Agricultural University, Kunming, Yunnan Province, China \\ ${ }^{2}$ Faculty of Food Science, Yunnan Agricultural University, Kunming, \\ Yunnan Province, China \\ ${ }^{3}$ Department of Husbandry and Veterinary, \\ Yunnan Vocational and Technical College of Agriculture, Kunming, \\ Yunnan Province, China \\ *These authors contributed equally to this study. \\ Corresponding authors: C.R. Ge / J.J. Jia \\ E-mail: gcrzal@126.com / junjingli2009@hotmail.com
}

Genet. Mol. Res. 15 (4): gmr15048967

Received July 14, 2016

Accepted October 11, 2016

Published December 2, 2016

DOI http://dx.doi.org/10.4238/gmr15048967

Copyright (C) 2016 The Authors. This is an open-access article distributed under the terms of the Creative Commons Attribution ShareAlike (CC BY-SA) 4.0 License.

ABSTRACT. Myostatin (MSTN) is expressed in the myotome and
developing skeletal muscles, and acts to regulate the number of muscle
fibers. Wuding chicken large body, developed muscle, high disease
resistance, and tender, delicious meat, and are not selected for fast
growth. Broiler chickens (Avian broiler) are selected for fast growth
and have a large body size and high muscle mass. Here, 240 one-day-
old chickens (120 Wuding chickens and 120 broilers) were examined.
Twenty chickens from each breed were sacrificed at days $1,30,60,90$, 
120 , and 150 . Breast and leg muscle samples were collected within 20 min of sacrifice to investigate the effects of MSTN gene expression on growth performance and carcass traits. Body weight, carcass traits, and skeletal muscle mass in Wuding chickens were significantly $(\mathrm{P}<0.05)$ lower than those in broiler chickens at all time points. Breast muscle MSTN mRNA was lower in Wuding chickens than in broilers before day $30(\mathrm{P}<0.05)$. After day 30, breast muscle MSTN expression was higher in Wuding chicken than in broilers $(\mathrm{P}<0.05)$. Leg muscle MSTN mRNA expression was higher in Wuding chicken than in broilers at all ages except for day $60(\mathrm{P}<0.05)$. Correlation analysis revealed that breast muscle MSTN expression has a greater effect in slow growing Wuding chickens than in the fast growing broilers. In contract, leg muscle MSTN mRNA level has a greater effect in broilers than in Wuding chickens. MSTN regulates growth performance and carcass traits in chickens.

Key words: Wuding Chicken; Myostatin gene; Body weight; Carcass traits

\section{INTRODUCTION}

Muscle growth is regulated through the proliferation and differentiation of myoblasts that express myogenic transcription factors. Myostatin (MSTN), also known as growth differentiation factor 8 (GDF-8), is a member of the transforming growth factor- $\beta$ (TGF- $\beta$ ) superfamily, which plays an important role in the regulation of skeletal muscle growth. During embryogenesis, MSTN is expressed in the myotome and developing skeletal muscles (McPherron et al., 1997; Langley et al., 2002), and acts to regulate the final number of muscle fibers. Many studies in mice have shown that MSTN negatively regulates the growth of muscle cells by inhibiting the transcriptional activity of myogenic differentiation antigen (MyoD) (Langley et al., 2002) family members and C2C12 cells (Taylor et al., 2001). Mutations in the $M S T N$ gene in mice prevent its expression resulting in the loss of function on muscle growth inhibition, which leads to excessive muscle development (Lee and McPherron, 1999). Mutations in the MSTN gene are associated with muscle hypertrophy (McPherron and Lee, 1997; Grobet et al., 1998), an increase in abdominal fat, abdominal fat percentage, birth weight, and breast muscle percentage in bovine (Karim et al., 2000), with muscle mass, carcass fat percentage, weight gain, and lamb carcass classification in sheep (Boman and Våge, 2009; Boman et al., 2010), and with MSTN expression, growth, muscle mass, and carcass composition traits in pigs (Stinckens et al., 2008). Moreover, naturally occurring mutations in the MSTN gene cause a similar double-muscled phenotype in cattle breeds, which exhibit a $20 \%$ increase in muscle mass (Grobet et al., 1998; Kambadur et al., 1997; McPherron et al., 1997).

In chicken, previous studies have shown that MSTN gene expression is increased in skeletal muscles during the second half of embryonic development and decline on hatching day (Kocamis and Killefer, 2002). The low levels of MSTN measured during the first weeks of life may contribute to the onset of skeletal muscle development in newly hatched chicks, which is dependent of the rapid initiation of neonatal metabolism (Mott and Ivarie, 2002). Nutrient supply regulates MSTN mRNA levels in chicken skeletal muscle (Guernec et al., 2004).

Genetics and Molecular Research 15 (4): gmr15048967 
However, how MSTN mRNA expression regulates growth, carcass traits, and development of skeletal muscle in poultry has not been elucidated. The expression of MSTN mRNA and its association with carcass composition trait and body weight have not been reported in chickens.

Wuding chicken is a local broiler-type breed in Yunnan, famous for its large body, attractive appearance, developed muscle, high disease resistance, and tender, delicious meat. Broiler chickens (Avian broiler) are selected for their fast growth rates, and they have a large body size and high muscle mass. Therefore, the objective of the present study was to investigate MSTN mRNA expression and to determine its association with body weight and carcass traits, using Wuding chicken and Avian broiler chicken as a model system.

\section{MATERIAL AND METHODS}

All procedures involving chickens received prior approval by the Animal Care and Use Committee of the Yunnan Province of China. The study was conducted in Yunnan Agricultural University of China.

\section{Ethics statement}

All experiments complied with the requirements of the Directory Proposals on the Ethical Treatment of Experimental Animals in China.

\section{Animals}

One-day-old Wuding chickens (local native breed of Yunnan Province of China) were purchased from the Chicken Farm of Yunnan Agricultural University. One-day-old broiler chicks (Avian) were purchased from the Chicken Farm of Kunming Zhengda Group. The chickens were sacrificed, the samples were collected, and the data were analyzed in the Key Laboratory of Animal Nutrition and Feed in Yunnan Agricultural University.

\section{Experimental design and dietary nutrient level}

The diet content was consistent with the formulation recommended by the National Research Council (1994) and Chinese Chicken Feeding Standard (2004) recommendations. A total of 240 one-day-old chicks, including 120 Wuding chicks and 120 broiler chicks (Avian) as a control were used in this study. Twenty chickens from each breed were sacrificed at day 0 and the remaining 100 chicks of each breed were reared under standard conditions on starter diets to day 30 , and then on adult chicken diets to day 150 . The composition of diets is provided in Table 1.

\section{Feeding and management}

The chickens had free access to feed and water during the entire rearing period. The chicks were reared in an environmentally controlled room. The brooding temperature was maintained at $35^{\circ} \mathrm{C}$ for the first 2 days, and then decreased gradually to $22^{\circ} \mathrm{C}$ until 30 days and thereafter maintained until the end of the experiment (day 60). At 30 days old, the chickens were randomly allocated to individual metabolism cages in an enclosed room, with ambient temperatures varying from $21^{\circ}-24^{\circ} \mathrm{C}$, under artificial fluorescent light on a light:dark cycle of 12:12 h. 
Table 1. Compositions and nutrient levels in the diets.

\begin{tabular}{l|c|c}
\hline Diet composition (\%) & Chick diet & Adult chicken diet \\
\hline Corn & 64.70 & 67.90 \\
\hline Soy protein & 30.2 & 18.1 \\
\hline Wheat bran & 0.00 & 0.00 \\
\hline Soya oil & 1.10 & 1.50 \\
\hline Calcium hydrogen phosphate & 1.50 & 0.60 \\
\hline Stone meal & 0.70 & 0.46 \\
\hline Midding flour & 0.41 & 0.07 \\
\hline Met & 0.08 & 0.35 \\
\hline Salt & 0.35 & 1.00 \\
\hline Compound premix ${ }^{1}$ & 1.00 & 100 \\
\hline Total & 100 & 2780 \\
\hline Nutrient levels & & 15.50 \\
\hline Metabolism energy (kcal/kg) & 2900 & 0.80 \\
\hline Crude protein (\%) & 19.30 & 0.64 \\
\hline Calcium (\%) & 0.85 & 0.37 \\
\hline Total phosphorus (\%) & 0.61 & 0.37 \\
\hline Available phosphorus (\%) & 0.37 & 0.75 \\
\hline Salt (\%) & 0.37 & 0.32 \\
\hline Lys (\%) & 0.98 & 0.60 \\
\hline Met (\%) & 0.39 & \\
\hline Methionine + Cystinol (\%) & 0.73 & \\
\hline
\end{tabular}

${ }^{1}$ Supplied per kilogram of diet: vitamin A, 15,000 IU; vitamin D3, $3300 \mathrm{IU}$; vitamin E, $62.5 \mathrm{mg}$; vitamin K, $3.6 \mathrm{mg}$; vitamin B1, $3 \mathrm{mg}$; vitamin B2, $9 \mathrm{mg}$; vitamin B6, $6 \mathrm{mg}$; vitamin B12, $0.03 \mathrm{mg}$; niacin, $60 \mathrm{mg}$; calcium pantothenate, $18 \mathrm{mg}$; folic acid, $1.5 \mathrm{mg}$; biotin, $0.36 \mathrm{mg}$; choline chloride, $600 \mathrm{mg}$; Fe, $80 \mathrm{mg}$; Cu, $12 \mathrm{mg} ; \mathrm{Zn}, 75 \mathrm{mg}$; $\mathrm{Mn}, 60 \mathrm{mg}$; I, $0.35 \mathrm{mg}$; Se, $0.15 \mathrm{mg}$; growth promoting agent, $30 \mathrm{mg}$; and antioxidant, $100 \mathrm{mg}$.

\section{Measurement of carcass traits}

Body weight (BW) was determined in the morning following a $16 \mathrm{~h}$-fast on days 0 , $30,60,90,120$, and 150 . The chickens were weighed by transfer to a transport box, which was placed on a tared digital scale (Shanghai Yizhan Weighing Apparatus Ltd, YZ $0.01 \mathrm{~g}$ to $10 \mathrm{~kg}$, China) to determine the body weight of conscious animals.

Carcass traits were measured on days 90,120, and 150. The estimated values of several important economic traits were determined, including carcass weight (CW), eviscerated weight (EW), semi-eviscerated weight (SEW), breast muscle weight (BMW), leg muscle weight (LMW), and abdominal fat weight (AFW). CW was measured using the live body with the blood and feathers removed. SEW was measured using the carcass with the esophagus, trachea, gastrointestinal tract, pancreas, spleen, and gonad removed. EW was measured using the SEW following the removal of the head, heart, claws, liver, glandular stomach, gizzard, and abdominal fat. The proportions of each of the above traits were calculated as dressing percentage (DP), eviscerated percentage (EP), semi-eviscerated percentage, breast muscle percentage, leg muscle percentage, and abdominal fat percentage, respectively (Zhang et al., 2009; Zhou et al., 2010). All the experiments were complied with the requirements of the Directory Proposals on the Ethical Treatment of Experimental Animals of China and animal care guidelines.

\section{Expression of MSTN mRNA}

Real-time PCR was performed to determine the expression of MSTN mRNA in muscle as described previously (Li et al., 2013). Breast and leg muscle samples were collected within 
20 min of the experimental chickens being sacrificed on days $0,30,60,90,120$, and 150 . Small samples of breast muscle and leg muscle were placed in sterile tubes (RNase-free) and immediately immersed in liquid nitrogen prior to storage at $-80^{\circ} \mathrm{C}$ pending subsequent analyses. Tissues were homogenized in Trizol-Reagent (Invitrogen Corporation, Carlsbad, CA, USA) and total RNA was isolated according to the manufacturer protocol. Kits provided by Trans Gen Biotech, Beijing, were used to reverse-transcribe mRNA into cDNA; a 10- $\mu \mathrm{L}$ reaction system was used, and the manufacturer instructions were followed. Real-time RTPCR analysis was performed to determine the expression of MSTN mRNA and 18S using the iCycler Real Time Detection System (Bio-Rad Laboratories Inc., USA) and SYBR Green master mix [iQTM SYBR-Green ${ }^{\circledR}$ Supermix, TaKaRa Biotechnology (Dalian) Co. Ltd. Add]. Quantitative PCR was performed in a volume of $25 \mu \mathrm{L}$, following the manufacturer instructions. The relevant gene sequences of Gallus gallus deposited in GenBank (ID: 373964) were used to design MSTN primers by primer premier 5.0. Primers specific for the MSTN gene were 5'-GCTTTTGATGAGACTGGACGAG-3' and 5'-AGCGGGTAGCGACAACATC-3' and the annealing temperature was $60^{\circ} \mathrm{C}$. Primers specific for chicken $18 \mathrm{~S}$ were 5'-CGCGTGCATTTATCAGACCA-3' and 5'-ACCCGTGGTCACCATGGTA-3', used as a reference, with an annealing temperature of $58^{\circ} \mathrm{C}$. The primers were synthesized by Shanghai Biological Engineering Co. Ltd., China. The specificity of the amplified product was verified by electrophoresis on $0.8 \%$ agarose gel and by DNA sequencing. Expression of all test genes was determined relative to that of $18 \mathrm{~S}$, which was used as a control gene. Gene expression data for muscle were obtained from 20 chickens of each breed and each age, and all assays were performed in triplicate. To compare the effects of different treatments on tissues, we performed $t$-tests on cycle threshold $(\mathrm{Ct})$ values of target MSTN gene expression normalized to $18 \mathrm{~S}$ threshold values.

\section{Statistical analysis}

All data were analyzed using Microsoft Excel (Office 2013) and the statistical package SPSS 21.0. For the analysis of carcass traits, data are reported as means \pm standard error from two breeds. For analysis of gene expression data, differences in the $\mathrm{Ct}$ values of $18 \mathrm{~S}$ and MSTN was calculated using a two-sample $t$-test. Delta $\mathrm{Ct}$ values for each treatment group were calculated as $\Delta \mathrm{CT}=\mathrm{CT}(\mathrm{MSTN})-\mathrm{CT}(18 \mathrm{~S})$. The fold change was calculated as 2 to the power $-\Delta \mathrm{Ct}$. Alpha $=0.05$ was used to determine statistical significance. To determine the significance of the correlation data, a single factor test was used.

\section{RESULTS}

\section{Body weight}

Data for BW gain over days 0 to 150 are summarized in Table 2 .

\section{Carcass traits}

Data for carcass traits at 90,120, 150 days are summarized in Tables 3, 4, and 5, respectively.

Genetics and Molecular Research 15 (4): gmr15048967 
Table 2. Mean body weight of different chickens from 0 to 150 days of age.

\begin{tabular}{l|c|c}
\hline Day & Wuding chickens BW $(\mathrm{g})$ & Broilers BW $(\mathrm{g})$ \\
\hline 0 & $31.63 \pm 2.64^{\mathrm{a} *}$ & $48.19 \pm 4.02^{\mathrm{a}}$ \\
\hline 30 & $228.65 \pm 19.05^{\mathrm{b} *}$ & $733.55 \pm 61.13^{\mathrm{b}}$ \\
\hline 60 & $662.11 \pm 110.35^{\mathrm{c} *}$ & $2377.56 \pm 96.26^{\mathrm{c}}$ \\
\hline 90 & $1264.71 \pm 35.84^{\mathrm{d} *}$ & $3244.42 \pm 82.01^{\mathrm{d}}$ \\
\hline 120 & $1832.16 \pm 124.36^{\mathrm{e} *}$ & $3960.50 \pm 72.46^{\mathrm{e}}$ \\
\hline 150 & $2157.55 \pm 85.59^{\mathrm{e} *}$ & $4577.50 \pm 98.68^{\mathrm{e}}$ \\
\hline
\end{tabular}

$\mathrm{BW}$, body weight. Means with different superscript letters differ between ages at $\mathrm{P}<0.05$. *Means with different superscript letters differ between breeds at $\mathrm{P}<0.05$. Throughout the whole growth period, the body weights of Wuding chickens were significantly $(\mathrm{P}<0.05)$ lower than those Broilers $(\mathrm{P}<0.05)$. The body weight of the two breeds increased significantly with age $(\mathrm{P}<0.05)$.

Table 3. Carcass traits of different chicken breeds from 90 days of age.

\begin{tabular}{l|c|c}
\hline Trait & Wuding chickens & Broilers \\
\hline CW $(\mathrm{g})$ & $1090.83 \pm 30.73^{\mathrm{a}}$ & $2935.87 \pm 89.88^{\mathrm{b}}$ \\
\hline SEW $(\mathrm{g})$ & $931.55 \pm 26.64^{\mathrm{a}}$ & $2653.71 \pm 86.06^{\mathrm{b}}$ \\
\hline EW $(\mathrm{g})$ & $788.92 \pm 26.16^{\mathrm{a}}$ & $2365.80 \pm 68.74^{\mathrm{b}}$ \\
\hline BMW $(\mathrm{g})$ & $144.25 \pm 6.87^{\mathrm{a}}$ & $726.66 \pm 30.37^{\mathrm{b}}$ \\
\hline LMW $(\mathrm{g})$ & $198.96 \pm 8.88^{\mathrm{a}}$ & $915.26 \pm 31.49^{\mathrm{b}}$ \\
\hline DP & $86.28 \pm 0.69$ & $90.25 \pm 0.67$ \\
\hline SEP & $73.70 \pm 0.82^{\mathrm{a}}$ & $72.79 \pm 0.88^{\mathrm{b}}$ \\
\hline EP & $62.46 \pm 1.23^{\mathrm{a}}$ & $30.51 \pm 0.46^{\mathrm{b}}$ \\
\hline BMP & $18.25 \pm 0.55^{\mathrm{a}}$ & $25.70 \pm 0.64$ \\
\hline LMP & $25.17 \pm 0.58$ & \\
\hline
\end{tabular}

$\mathrm{CW}$, carcass weight; SEW, semi-eviscerated weight; EW, eviscerated weight; BMW, breast muscle weight; LMW, leg muscle weight; DP, dressing percentage; SEP, semi-eviscerated percentage; EP, eviscerated percentage; BMP, breast muscle percentage; LMP, leg muscle percentage. Means with different superscripts differ between breeds at $\mathrm{P}<0.05$.

Table 4. Carcass traits of different chicken breeds from 120 days of age.

\begin{tabular}{l|c|c}
\hline & Mini chickens & Broilers \\
\hline CW $(\mathrm{g})$ & $1586.64 \pm 109.79^{\mathrm{a}}$ & $3576.19 \pm 71.30^{\mathrm{b}}$ \\
\hline SEW $(\mathrm{g})$ & $1355.15 \pm 95.87^{\mathrm{a}}$ & $3240.44 \pm 62.54^{\mathrm{b}}$ \\
\hline EW $(\mathrm{g})$ & $1140.41 \pm 84.13^{\mathrm{a}}$ & $2789.80 \pm 57.48^{\mathrm{b}}$ \\
\hline BMW $(\mathrm{g})$ & $221.78 \pm 19.14^{\mathrm{a}}$ & $914.25 \pm 26.82^{\mathrm{b}}$ \\
\hline LMW $(\mathrm{g})$ & $308.20 \pm 29.97^{\mathrm{a}}$ & $982.69 \pm 26.66^{\mathrm{b}}$ \\
\hline DP & $86.51 \pm 0.64^{\mathrm{a}}$ & $80.27 \pm 0.55^{\mathrm{b}}$ \\
\hline SEP & $73.77 \pm 0.67^{\mathrm{a}}$ & $70.41 \pm 0.45^{\mathrm{b}}$ \\
\hline EP & $61.87 \pm 0.76^{\mathrm{a}}$ & $32.72 \pm 0.60^{\mathrm{b}}$ \\
\hline BMP & $19.37 \pm 0.59^{\mathrm{a}}$ & $28.06 \pm 0.75$ \\
\hline LMP & $26.38 \pm 0.81$ & \\
\hline
\end{tabular}

CW, carcass weight; SEW, semi-eviscerated weight; EW, eviscerated weight; BMW, breast muscle weight; LMW, leg muscle weight; DP, dressing percentage; SEP, semi-eviscerated percentage; EP, eviscerated percentage; BMP, breast muscle percentage; LMP, leg muscle percentage. Means with different superscripts differ between breeds at $\mathrm{P}<0.05$.

The CW, SEW, EW, BMW, LMW, and AFW, and the ratios of each of the above traits in Wuding chicken were significantly $(\mathrm{P}<0.05)$ lower than those in Broilers at 90, 120, and 150 days.

\section{MSTN expression levels}

The expression of MSTN mRNA is summarized in Figure 1. MSTN mRNA expression levels were lower in breast muscle from Wuding chicken than in that from broilers before

Genetics and Molecular Research 15 (4): gmr15048967 
day $30(\mathrm{P}<0.05)$. After day 30, the expression levels in the breast muscle were higher in Wuding chicken than in broilers $(\mathrm{P}<0.05)$. Moreover, MSTN mRNA expression levels in the leg muscle were greater in Wuding chicken than in broilers at all ages, with the exception of day $60(\mathrm{P}<0.05)$.

Table 5. Carcass traits in different chicken breeds from 150 days of age.

\begin{tabular}{l|c|c}
\hline & Mini chickens & Broilers \\
\hline CW $(\mathrm{g})$ & $1880.48 \pm 76.79^{\mathrm{a}}$ & $4160.29 \pm 96.05^{\mathrm{b}}$ \\
\hline SEW $(\mathrm{g})$ & $1620.33 \pm 81.00^{\mathrm{a}}$ & $3829.43 \pm 89.54^{\mathrm{b}}$ \\
\hline EW $(\mathrm{g})$ & $1337.24 \pm 69.50^{\mathrm{a}}$ & $3356.18 \pm 84.15^{\mathrm{b}}$ \\
\hline BMW $(\mathrm{g})$ & $288.49 \pm 13.44^{\mathrm{a}}$ & $1109.55 \pm 33.51^{\mathrm{b}}$ \\
\hline LMW $(\mathrm{g})$ & $367.97 \pm 25.40^{\mathrm{a}}$ & $993.47 \pm 42.99^{\mathrm{b}}$ \\
\hline DP & $87.14 \pm 0.54^{\mathrm{a}}$ & $91.15 \pm 0.31^{\mathrm{b}}$ \\
\hline SEP & $74.84 \pm 1.67^{\mathrm{a}}$ & $83.89 \pm 0.31^{\mathrm{b}}$ \\
\hline EP & $61.67 \pm 1.41^{\mathrm{a}}$ & $73.48 \pm 0.45^{\mathrm{b}}$ \\
\hline BMP & $21.76 \pm 0.35^{\mathrm{a}}$ & $33.03 \pm 0.48^{\mathrm{b}}$ \\
\hline LMP & $27.16 \pm 0.61$ & $29.38 \pm 0.62$
\end{tabular}

CW, carcass weight; SEW, semi-eviscerated weight; EW, eviscerated weight; BMW, breast muscle weight; LMW, leg muscle weight; DP, dressing percentage; SEP, semi-eviscerated percentage; EP, eviscerated percentage; BMP, breast muscle percentage; LMP, leg muscle percentage. Means with different superscripts differ between breeds at $\mathrm{P}<0.05$.

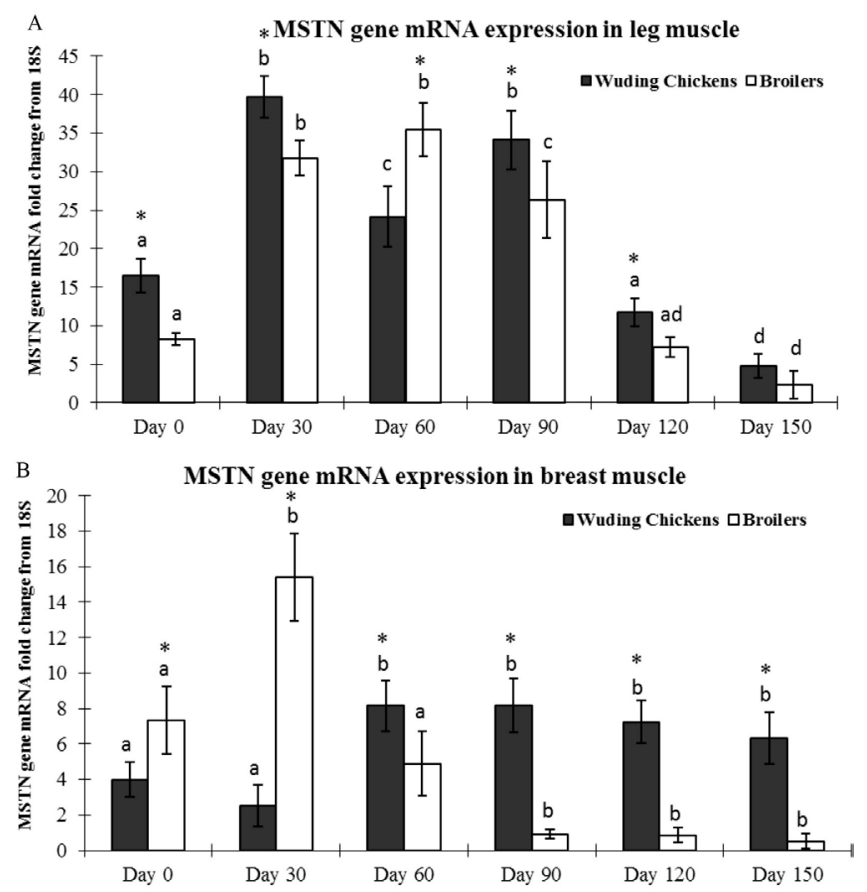

Figure 1. mRNA abundance based on the extraction of total RNA and subsequent real-time PCR analysis for MSTN in breast muscle (A) and leg muscle (B) from two chicken breeds at 0, 30, 60, 90, and 120 days. Data are reported as mean ratio \pm standard error of MSTN mRNA: 18S rRNA for chickens from each breed in each age or each diet group from two breeds. Lowercase letters: means with different superscripts differ between age at $\mathrm{P}<$ 0.05 ; * means with different superscripts differ between breeds at $\mathrm{P}<0.05$.

Genetics and Molecular Research 15 (4): gmr15048967 


\section{Correlation analysis}

Correlation analyses of BW, carcass traits, and MSTN mRNA expression in Wuding chicken and broilers are summarized in Tables 6 and 7. There was a positive correlation between BW and carcass traits in the two breeds. Discrepancies in the association between tissue-specific MSTN mRNA expression and body carcass traits were observed in the two breeds. Thus, the expression of breast muscle MSTN mRNA in Wuding chicken was negatively correlated $(\mathrm{P}<$ 0.05 ) with CW, SEW, EW, BMW, and LMW. Leg muscle MSTN mRNA expression in Wuding chicken was negatively correlated with carcass traits, but no differences were observed $(\mathrm{P}<$ 0.05). MSTN mRNA expression in breast muscle of broilers was negatively correlated with BW $(\mathrm{P}<0.05)$. Leg muscle MSTN mRNA expression in broilers was negatively correlated with CW, SEW, EW, BMW, LMW, and AFW $(\mathrm{P}<0.05)$.

Table 6. Correlation analysis between LW, carcass traits, and MSTN mRNA expression in Wuding chickens.

\begin{tabular}{l|c|c|c|c|c|c|c|c}
\hline & LW & CW & SEW & EW & BMW & LMW & MSTN-BM & MSTN-LM \\
\hline LW & 1 & & & & & & \\
\hline CW & $0.994^{* *}$ & 1 & & & & & \\
\hline SEW & $0.969^{* *}$ & $0.982^{* *}$ & 1 & & & & \\
\hline EW & $0.961^{* *}$ & $0.976^{* *}$ & $0.992^{* *}$ & 1 & & & & \\
\hline BMW & $0.890^{* *}$ & $0.924^{* *}$ & $0.941^{* *}$ & $0.945^{* *}$ & 1 & & & \\
\hline LMW & $0.880^{* *}$ & $0.913^{* *}$ & $0.952^{* *}$ & $0.966^{* *}$ & $0.966^{* *}$ & 1 & & \\
\hline MSTN-BM & $-0.413^{* *}$ & $-0.394^{* *}$ & $-0.372^{* *}$ & $-0.369^{* *}$ & $-0.393^{* *}$ & $-0.377^{* *}$ & 1 & \\
\hline MSTN-LM $^{\mathrm{b}}$ & $-0.724^{* *}$ & $-0.712^{* *}$ & $-0.682^{* *}$ & $-0.655^{* *}$ & $-0.663^{* *}$ & $-0.577^{* *}$ & $0.512^{* *}$ & 1 \\
\hline
\end{tabular}

LW, mean live weight; CW, carcass weight; SEW, semi-eviscerated weight; EW, eviscerated weight; BMW, breast muscle weight; LMW, leg muscle weight. ${ }^{a}$ Mean MSTN expression in breast muscle. ${ }^{b}$ Mean MSTN expression in leg muscle. **Means with extremely significant correlation $(\mathrm{P}<0.01)$.

Table 7. Correlation analysis between mean live weight (LW), carcass traits, and MSTN mRNA expression in Broilers.

\begin{tabular}{l|c|c|c|c|c|c|c|c}
\hline & LW & CW & SEW & EW & BMW & LMW & MSTN-BM & MSTN-LM \\
\hline LW & 1 & & & & & & \\
\hline CW & $0.992^{* *}$ & 1 & & & & & \\
\hline SEW & $0.990^{* *}$ & $0.996^{* *}$ & 1 & & & & \\
\hline EW & $0.984^{* *}$ & $0.985^{* *}$ & $0.990^{* *}$ & 1 & & & & \\
\hline BMW & $0.925^{* *}$ & $0.938^{* *}$ & $0.946^{* *}$ & $0.953^{* *}$ & 1 & & & \\
\hline LMW & $0.929^{* *}$ & $0.943^{* *}$ & $0.940^{* *}$ & $0.940^{* *}$ & $0.893^{* *}$ & 1 & & \\
\hline MSTN-BM $^{\mathrm{a}}$ & $-0.295^{*}$ & $-0.310^{*}$ & $-0.317^{*}$ & $-0.327^{*}$ & $-0.338^{* *}$ & $-0.306^{*}$ & 1 & \\
\hline MSTN-LM $^{\mathrm{b}}$ & $-0.666^{* *}$ & $-0.644^{* *}$ & $-0.643^{* *}$ & $-0.613^{* *}$ & $-0.613^{* *}$ & $-0.562^{* *}$ & 0.199 & 1 \\
\hline
\end{tabular}

Carcass traits: CW, carcass weight; SEW, semi-eviscerated weight; EW eviscerated weight; BMW, breast muscle weight; LMW, leg muscle weight. a Mean MSTN expression in breast muscle. ${ }^{b}$ Mean MSTN expression in leg muscle. *Means differ at $\mathrm{P}<0.05$. **Means differ at $\mathrm{P}<0.01$.

\section{DISCUSSION}

Several factors affect production and carcass performance in chicken, including breed or strain, sex, nutrition, housing, and stocking rate. However, breed plays an important role in determining carcass characteristics and muscle mass. Breed significantly affects BW (Shahin and Elazeem, 2005; Jaturasitha et al., 2008; Bhattacharya et al., 2015), carcass weight (Ojedapo et al., 2008; Olawumi and Fagbuaro, 2011), breast and leg muscle weight fat and edible giblet weight (Ojedapo et al., 2008), and back and drumstick weights (Ojedapo et al., 2008) in

Genetics and Molecular Research 15 (4): gmr15048967 
chickens. Consistent with those reports, CW, BMW, LMW, AFW, DP, and EP were significantly lower in Wuding chickens than in broilers. Compared to Jingle fowl and Wuding chickens, broiler chickens have been selected for their fast growth rate, which has significantly increased the productive and carcass performance and has been associated with changes in morphology and physiology (Rong et al., 2011). Domestic animals have evolved genetic adaptations to the farm environment, and have been subjected to strong human-driven selection resulting to marked phenotypic changes in their morphology, physiology, and behavior (Andersson, 2001). Identifying the genetic changes underlying these developments provides new insight into the mechanisms by which genetic variation shapes phenotypic diversity (Rubin et al., 2010). Indeed, the genetic diversity present in modern commercial pure lines has been estimated at just $50 \%$ of that present in ancestral breeds in jungle fowl (Muir et al., 2008).

In general, DP and EP are considered the main indicators of meat yield in chicken (Lehmann, 2006). DP exceeding $80 \%$ and EP up to $60 \%$ are considered good signs of meat performance (Zhang, 2004). In the present study, broiler chickens had high muscle mass and excellent carcass characteristics than Wuding chickens. DP and EP have been shown to be 86.28 and $62.46 \%$ for Wuding chickens, 90.25 and $72.79 \%$ for broilers, respectively. Wuding chickens might carry potential excellent genetic genes for breast meat yield due to their high percentage of muscle mass (Rong et al., 2011). The correlation analysis in the present study showed that BW was positively associated with CW, SEW, and EW in both breeds. In agreement with other reports, there was high correlation between BW and carcass traits in the present study (Chen et al., 2014).

Myostatin is a highly conserved, potent regulator of growth and differentiation of skeletal muscle in many species, from teleost fishes to humans, although its mechanisms of action are incompletely understood (Morissette et al., 2006). MSTN mRNA expression was detected in a wide range of tissues in chicken, and its tissue-specific expression was similar to that reported in fishes, but different to that reported in mammals. During the embryonic stage in chicken, MSTN was shown to be expressed even before the establishment of the myogenic lineage (Kocamis and Killefer, 2002). It was suggested that chicken MSTN might play a major role in the morphogenesis of chicken liver, heart, brain, and intestine (Sundaresan et al., 2008). In the present study, expression of MSTN mRNA in breast muscle was greater in broiler chickens than in Wuding chickens on day 30. Wuding chicken is reared solely as a local breed and has not been selected for fast growth (Rong et al., 2011). Lower MSTN mRNA in muscle of 30-day-old Wuding chickens suggested that the chicken MSTN gene might play an important role in the regulation of muscle fiber development.

Myostatin is a potent growth and differentiation factor involved in skeletal muscle formation in vertebrates (Castelhano-Barbosa et al., 2005). During the early embryonic stages, myostatin is restricted to the myotome compartment of the developing somites, and myostatin has been proposed to play an essential role in skeletal muscle growth and development (McPherron et al., 1997). Myostatin inhibits myoblast proliferation (Bass et al., 1999) by preventing their progression from the G1 to the S phase of the cell cycle (Thomas et al., 2000). In chicken, the developmental pattern of myostatin mRNA expression coincides roughly with the progression of muscle fiber formation (Kocamis and Killefer, 2002). In the present study, MSTN mRNA in breast muscle was expressed at lower levels in Wuding chicken than in broilers before day 30. After day 30, MSTN mRNA in breast muscle was higher in Wuding chicken than in broilers. Expression of MSTN mRNA in leg muscle was higher in Wuding chicken than in broilers at all ages, with the exception of day 60 . Broilers selected for growth 
performance and muscle yield might have led to changes in the MSTN gene sequence and regulation. Consistent with previous reports (Zhang et al., 2012), a negative effect of the chicken $M S T N$ gene on the regulation of growth performance and carcass traits was observed in the present study.

The MSTN gene has been closely linked with the growth and development of animals, and its expression is negatively correlated with muscle weight in channel catfish (Weber et al., 2005). Variation in the MSTN gene is associated with meat production in New Zealand Romney sheep, skeletal muscle growth, DP, leg muscle rate, and other carcass traits in sheep (Boman and Våge, 2009; Wiener et al., 2009; Hickford et al., 2010). Mutations in the MSTN gene significantly affected BW in Bian chicken, and the correlation between growth rate and mortality rate in broiler chickens (Zhang et al., 2012). MSTN mRNA expression in muscle was negatively associated with BW and carcass traits in both breeds in present study. Consistent with a previous report (Guimaraes et al., 2007) that MSTN mRNA expression was negatively correlated with growth rate and meat quality traits in pig. MSTN mRNA expression in pig has a greater effect in fast-growing animals than in slow-growing animals. However, there were differences noted in the correlation of tissue-specific MSTN mRNA expression with body carcass traits in the two breeds. MSTN mRNA expression in breast muscle was negatively correlated with CW, SEW, EW, BMW, and LMW in Wuding chickens and with BW in broilers. MSTN mRNA expression in leg muscle in broiler chicken was negatively correlated with CW, SEW, EW, BMW, and LMW. The present data suggest that expression of MSTN mRNA in breast and leg muscle has more of an effect in slow growing Wuding chickens than in fast growing broilers.

It is clear that the MSTN gene has an important role in the regulation of growth performance and skeletal muscle mass in chickens. Broiler chickens selected for fast growth exhibit decreased MSTN mRNA expression in skeletal muscle, which is associated with an increase in muscle mass. The results of the present study further strengthen the notion that the MSTN gene may be useful in molecular breeding in chicken owing to its negative regulatory effect on muscle mass.

\section{Conflicts of interest}

The authors declare no conflict of interest.

\section{ACKNOWLEDGMENTS}

Research supported by the National Natural Science Foundation Research Projects (\#31260532, \#31560618, and \#31572359) and the 13th Five-Year Rural Areas of National Science and Technology Project (\#2015BAD03B03-4).

\section{REFERENCES}

Andersson L (2001). Genetic dissection of phenotypic diversity in farm animals. Nat. Rev. Genet. 2: 130-138. http:// dx.doi.org/10.1038/35052563

Bass J, Oldham J, Sharma M and Kambadur R (1999). Growth factors controlling muscle development. Domest. Anim. Endocrinol. 17: 191-197. http://dx.doi.org/10.1016/S0739-7240(99)00036-3

Bhattacharya TK, Chatterjee RN, Dushyanth K and Shukla R (2015). Cloning, characterization and expression of myostatin (growth differentiating factor-8) gene in broiler and layer chicken (Gallus gallus). Mol. Biol. Rep. 42: 319-327. http:// dx.doi.org/10.1007/s11033-014-3753-x

Genetics and Molecular Research 15 (4): gmr15048967 
Boman IA and Våge DI (2009). An insertion in the coding region of the myostatin (MSTN) gene affects carcass conformation and fatness in the Norwegian Spaelsau (Ovis aries). BMC Res. Notes 2: 98. http://dx.doi.org/10.1186/1756-0500-2-98

Boman IA, Klemetsdal G, Nafstad O, Blichfeldt T, et al. (2010). Impact of two myostatin (MSTN) mutations on weight gain and lamb carcass classification in Norwegian White Sheep (Ovis aries). Genet. Sel. Evol. 42: 4. http://dx.doi. org/10.1186/1297-9686-42-4

Castelhano-Barbosa EC, Gabriel JE, Alvares LE, Monteiro-Vitorello CB, et al. (2005). Temporal and spatial expression of the myostatin gene during chicken embryo development. Growth Dev. Aging 69: 3-12.

Chen JB, Tao L, Du BW, Yang FX, et al. (2014). Analysis of correlation between the slaughter performance and meat quality of Frizzle chicken. Agric. Sci. Technol. 15: 258-260.

Chinese Chicken Feeding Standard (2004). First edition. National Agricultural Ministry Press, Bejing.

Grobet L, Poncelet D, Royo LJ, Brouwers B, et al. (1998). Molecular definition of an allelic series of mutations disrupting the myostatin function and causing double-muscling in cattle. Mamm. Genome 9:210-213.http://dx.doi.org/10.1007/ $\underline{\mathrm{s} 003359900727}$

Kambadur R, Sharma M, Smith TP and Bass JJ (1997). Mutations in myostatin (GDF8) in double-muscled Belgian Blue and Piedmontese cattle. Genome Res. 7: 910-916.

Guernec A, Chevalier B and Duclos MJ (2004). Nutrient supply enhances both IGF-I and MSTN mRNA levels in chicken skeletal muscle. Domest. Anim. Endocrinol. 26: 143-154.http://dx.doi.org/10.1016/j.domaniend.2003.10.001

Guimaraes S, Stahl CH, Lonergan SM, Geiger B, et al. (2007). Myostatin promoter analysis and expression pattern in pigs. Livest. Sci. 112: 143-150. http://dx.doi.org/10.1016/j.livsci.2007.02.004

Hickford JG, Forrest RH, Zhou H, Fang Q, et al. (2010). Polymorphisms in the ovine myostatin gene (MSTN) and their association with growth and carcass traits in New Zealand Romney sheep. Anim. Genet. 41: 64-72. http://dx.doi. org/10.1111/j.1365-2052.2009.01965.x

Jaturasitha S, Srikanchai T, Kreuzer M and Wicke M (2008). Differences in carcass and meat characteristics between chicken indigenous to northern Thailand (Black-boned and Thai native) and imported extensive breeds (Bresse and Rhode Island red). Poult. Sci. 87: 160-169.http://dx.doi.org/10.3382/ps.2006-00398

Karim L, Coppieters W, Grobet L, Valentini A, et al. (2000). Convenient genotyping of six myostatin mutations causing double-muscling in cattle using a multiplex oligonucleotide ligation assay. Anim. Genet. 31: 396-399. http://dx.doi. org/10.1046/j.1365-2052.2000.00684.x

Kocamis H and Killefer J (2002). Myostatin expression and possible functions in animal muscle growth. Domest. Anim. Endocrinol. 23: 447-454. http://dx.doi.org/10.1016/S0739-7240(02)00178-9

Langley B, Thomas M, Bishop A, Sharma M, et al. (2002). Myostatin inhibits myoblast differentiation by down-regulating MyoD expression. J. Biol. Chem. 277: 49831-49840.http://dx.doi.org/10.1074/jbc.M204291200

Lee SJ and McPherron AC (1999). Myostatin and the control of skeletal muscle mass. Curr. Opin. Genet. Dev. 9: 604-607. http://dx.doi.org/10.1016/S0959-437X(99)00004-0

Lehmann L (2006). Principal components analysis applied to performance and carcass traits in the chicken. Anim. Res. 55: 419-425. http://dx.doi.org/10.1051/animres:2006022

Li Q, Xu Z, Liu L, Yu H, et al. (2013). Effects of breeds and dietary protein levels on the growth performance, energy expenditure and expression of avUCP mRNA in chickens. Mol. Biol. Rep. 40: 2769-2779. http://dx.doi.org/10.1007/ $\underline{\text { s11033-012-2030-0 }}$

McPherron AC and Lee SJ (1997). Double muscling in cattle due to mutations in the myostatin gene. Proc. Natl. Acad. Sci. USA 94: 12457-12461.http://dx.doi.org/10.1073/pnas.94.23.12457

McPherron AC, Lawler AM and Lee SJ (1997). Regulation of skeletal muscle mass in mice by a new TGF- $\beta$ superfamily member. Nature 387: 83-90. http://dx.doi.org/10.1038/387083a0

Morissette MR, Cook SA, Foo S, McKoy G, et al. (2006). Myostatin regulates cardiomyocyte growth through modulation of Akt signaling. Circ. Res. 99: 15-24. http://dx.doi.org/10.1161/01.RES.0000231290.45676.d4

Mott I and Ivarie R (2002). Expression of myostatin is not altered in lines of poultry exhibiting myofiber hyper- and hypoplasia. Poult. Sci. 81: 799-804. http://dx.doi.org/10.1093/ps/81.6.799

Muir WM, Wong GKS, Zhang Y, Wang J, et al. (2008). Genome-wide assessment of worldwide chicken SNP genetic diversity indicates significant absence of rare alleles in commercial breeds. Proc. Natl. Acad. Sci. USA 105: 1731217317. http://dx.doi.org/10.1073/pnas.0806569105

National Research Council (1994). Nutrient requirements of poultry. 9th edn. National Academic Press, Washington, DC.

Ojedapo LO, Akinokun O, Adedeji TA, Olayeni TB, et al. (2008). Effect of strain and sex on carcass characteristics of three commercial broilers reared on deep litter system in the Derived Savannah area of Nigeria. World J. Agric. Sci. 4: 487-491.

Olawumi SO and Fagbuaro S (2011). Productive Performance of three commercial broiler genotypes reared in the Derived Savannah Zone of Nigeria. Int. J. Agric. Res. 6: 7 98-804.

Genetics and Molecular Research 15 (4): gmr15048967 
Rong H, Chen XB, Xiong BL, Wan QS, et al. (2011). Study on the germplasm characteristic of Yunnan Daweishan Mini Chickens. Yunnan Nong Ye Da Xue Xue Bao 26: 48-53.

Rubin CJ, Zody MC, Eriksson J, Meadows JR, et al. (2010). Whole-genome resequencing reveals loci under selection during chicken domestication. Nature 464: 587-591.http://dx.doi.org/10.1038/nature08832

Shahin KA and Elazeem FA (2005). Effects of breed and sex and diet and their interactions on carcass composition and tissue weight distribution of broiler chickens. Arch. Tierzil 48: 612-626.

Stinckens A, Luyten T, Bijttebier J, Van den Maagdenberg K, et al. (2008). Characterization of the complete porcine MSTN gene and expression levels in pig breeds differing in muscularity. Anim. Genet. 39: 586-596. http://dx.doi. org/10.1111/j.1365-2052.2008.01774.x

Sundaresan NR, Saxena VK, Singh R, Jain P, et al. (2008). Expression profile of myostatin mRNA during the embryonic organogenesis of domestic chicken (Gallus gallus domesticus). Res. Vet. Sci. 85: 86-91. http://dx.doi.org/10.1016/j. rvsc.2007.09.014

Taylor WE, Bhasin S, Artaza J, Byhower F, et al. (2001). Myostatin inhibits cell proliferation and protein synthesis in C2C12 muscle cells. Am. J. Physiol. Endocrinol. Metab. 280: E221-E228.

Thomas M, Langley B, Berry C, Sharma M, et al. (2000). Myostatin, a negative regulator of muscle growth, functions by inhibiting myoblast proliferation. J. Biol. Chem. 275: 40235-40243. http://dx.doi.org/10.1074/jbc.M004356200

Weber TE, Small BC and Bosworth BG (2005). Lipopolysaccharide regulates myostatin and MyoD independently of an increase in plasma cortisol in channel catfish (Ictalurus punctatus). Domest. Anim. Endocrinol. 28: 64-73. http:// dx.doi.org/10.1016/j.domaniend.2004.05.005

Wiener P, Woolliams JA, Frank-Lawale A, Ryan M, et al. (2009). The effects of a mutation in the myostatin gene on meat and carcass quality. Meat Sci. 83: 127-134. http://dx.doi.org/10.1016/j.meatsci.2009.04.010

Zhang GX, Zhao XH, Wang JY, Ding FX, et al. (2012). Effect of an exon 1 mutation in the myostatin gene on the growth traits of the Bian chicken. Anim. Genet. 43: 458-459. http://dx.doi.org/10.1111/j.1365-2052.2011.02274.x

Zhang H (2004). On slaughter performance of Liyang chicken. China Poult. 2: 31-32.

Zhang ZR, Liu YP, Yao YG, Jiang XS, et al. (2009). Identification and association of the single nucleotide polymorphisms in calpain3 (CAPN3) gene with carcass traits in chickens. BMC Genet. 10: 10. http://dx.doi.org/10.1186/1471-2156-10-10

Zhou Y, Liu Y, Jiang X, Du H, et al. (2010). Polymorphism of chicken myocyte-specific enhancer-binding factor 2A gene and its association with chicken carcass traits. Mol. Biol. Rep. 37: 587-594. http://dx.doi.org/10.1007/s11033-009-9838-2

Genetics and Molecular Research 15 (4): gmr15048967 